\title{
BMI Patient Injury Anterior Cruciate Ligament (ACL) Post Operative And Conservative Action
}

\author{
Bhekti Lestari1*, Damayanti Tinduh $^{1}$, dan Ria Lumintuarso ${ }^{2}$ \\ ${ }^{1}$ Universitas Airlangga, Surabaya, Indonesia \\ ${ }^{2}$ Universitas Negeri Yogyakarta, Indonesia \\ lestaribhekti@ymail.com
}

\begin{abstract}
ACL injuries have a high number of prevalence, most feared by sportsman and expensive in rehabilitation cost. Body Mass Index (BMI) is on of most risk factors for ACL injury. Operative treatment and conservative treatment are the exact solution for handling ACL injuries. The aim of this study is to determine the difference of mean Body Mass Index (BMI) in patients with ACL injury post-operative and conservative treatments. Type of this research was observational with post-test only design and used a cross-sectional approach. Fifteen operative patients and fifteen conservative patients were selected based on inclusion and exclusion criteria, divided into OT (Operative Treatment) and KT (Conservative Treatment) groups. Body weight and body height measurements were carried out to obtain Body Mass Index (BMI). The results obtained by means and $\mathrm{p}$ value are OT group $24,59 \pm 5,00 \mathrm{Kg} / \mathrm{m}^{2}>\mathrm{KT}$ group $23,49 \pm 2,60 \mathrm{Kg} / \mathrm{m}^{2}(\mathrm{p}=0,256>0,05)$. The results can be concluded that there is no significant difference BMI between OT and KT group.
\end{abstract}

Keywords: BMI, ACL, Operative, Conservative 


\section{STRADA Jurnal Ilmiah Kesehatan}

DOI: $10.30994 /$ sjik.v9i1.263

ISSN: 2252-3847 (print); 2614-350X (online)

Vol.9 No.1. May 2020. Page.6-11

\section{INTRODUCTION}

Sports injuries are injuries that occur in the musculoskeletal system or other systems so that it can affect the musculoskeletal system. This can occur both during practice, matches and afterwards (Junaidi, 2013). One injury that often occurs in sports is Anterior Cruciate Ligament (ACL) injury. The majority of ACL injuries occur through non-contact mechanisms (Lin et al., 2012) such as when knee hyperextents (Singh, 2018), rotate (Holt, 2018), imperfect landings (B. Holmquist \& C. Mc Farland, 2014), zig-zag movements and sudden changes in direction as in football, basketball and futsal movements (Muhammad I. Zein, 2013).

Risk factors for ACL injuries consist of intrinsic and extrinsic factors. Intrinsic factors are still divided into intrinsically modifiable (muscular strength and flexibility) and cannot be modified or controlled (anatomical structure). Extrinsic factors are factors that originate from outside such as surface surfaces (Craig E. Pfeifer et al., 2018). Another intrinsic and modifiable risk factor is the Body Mass Index (BMI) (Rurin Ardiyani et al., 2016).

The estimated incidence of ACL injuries in several countries such as the USA, Denmark, Norway, Sweden, Germany and New Zealand based on records from the 1990s-2006 reached an average of 29-38 per 100,000 people per period (Singh, 2018). The Central Java Health Office in 2007 reported an incidence of knee and lower limbs reaching $49.4 \%$ and the West Sulawesi Health Office in 2007 reported an incidence of 38.9\%. (Sport Clinic Dr. Soetomo Hospital, 2012). For athletes who have ACL injuries, more than 50\% are at risk of exposure to OA 10-20 years after injury (Stephen R. Stephan et al., 2015).

According to Mather et al. (2013), there are 2 primary measures for the treatment of torn ACL injuries: reconstruction operations and rehabilitation of structures. Surgery immediately after injury can prevent imbalance and re-injury and provide a higher quality of life for patients (B. Holmquist \& C. Mc Farland, 2014). Operating costs result in high health costs (Rima L. Borgadus et al., 2017). For individuals who choose not to take surgery, rehabilitation of an injured knee is often recommended to regain function and help prevent instability (B. Holmquist \& C. Mc Farland, 2014). Non-operative therapy can be given in cases of partial ACL tears that do not cause symptoms of instability (Muhammad I. Zein, 2013).

\section{METHODS}

The type of research that will be carried out is an observational study with a post test only design and uses a cross-sectional approach. The study population was ACL injured patients at Jogja Sports Clinic (JSC), Special Region of Yogyakarta. The research sample is determined by total sampling. Samples were obtained based on inclusion criteria undergoing post-ACL injury rehabilitation at JSC, athletes or people who actively exercised before and after injury, had a history of ACL, conservative ACL injuries within a minimum of 6 months from injury onset and a maximum of 2 years, ACL injuries operative group was at a minimum 6 months from reconstruction and maximum 2 years and between 17-30 years old. Height measurements using a height measurement tool (microtoise / stadiometer) and body weight measured using weight scales. Data analysis begins with descriptive analysis, normality test and different test using independent t-test.

\section{RESULTS}

BMI variables are presented in descriptive statistics based on minimum, maximum, average and standard deviation values. 


\section{STRADA Jurnal Ilmiah Kesehatan}

DOI: $10.30994 /$ sjik.v9i1.263

ISSN: 2252-3847 (print); 2614-350X (online)

Vol.9 No.1. May 2020. Page.6-11

Table 1. Descriptive statistics of BMI variables.

Variable $\mathrm{n} \quad$ Operative Action (OT)

Mean $\pm \quad$ Mean \pm

Min Max Standard Min Max Standard

Deviation Deviation

\begin{tabular}{cccccccc}
\hline Height $(\mathrm{cm})$ & 15 & 150 & 181 & $168,27 \pm 8,79$ & 153 & 183 & $166,67 \pm 7,88$ \\
\hline Weight $(\mathrm{Kg})$ & 15 & 55 & 107 & $69,37 \pm 13,72$ & 50 & 80 & $65,33 \pm 8,93$ \\
\hline BMI $\left(\mathrm{Kg} / \mathrm{m}^{2}\right)$ & 15 & $\begin{array}{c}17,3 \\
9\end{array}$ & $\begin{array}{c}39,3 \\
4\end{array}$ & $24,59 \pm 4,50$ & $\begin{array}{c}20,2 \\
1\end{array}$ & $\begin{array}{c}29,6 \\
8\end{array}$ & $23,49 \pm 2,60$ \\
\hline
\end{tabular}

OT: operative action,

$\mathrm{KT}$ : conservative action

The results of the normality test using the Shapiro-Wilk test. This normality test aims to determine the difference test using parametric or non-parametric.

Table 2. Normality test results Shapiro-Wilk test.

\begin{tabular}{lccc}
\hline Group & $\mathrm{N}$ & Body Mass Index $\left(\mathrm{Kg} / \mathrm{m}^{2}\right)$ & $\mathrm{p}$ \\
\cline { 3 - 3 } & & Mean $\pm \mathrm{SD}$ & \\
\hline OT & 15 & $24,59 \pm 4,50$ & \\
KT & 15 & $23,49 \pm 2,60$ & 0,073 \\
\hline
\end{tabular}

OT: operative action,

KT: conservative action,

BMI: Body Mass Index

Based on the results of the normality test in table 2, the data of the IMT variable is normally distributed ( $p>0.05$ ), so that the different test will be continued using the independent t-test.

Independent t-test was conducted to find out whether there were differences between the mean IMT of the OT group and the IMT of the KT group.

Table 3. Independent t-test test results.

\begin{tabular}{lccc}
\hline Kelompok & $\mathrm{N}$ & $\mathrm{IMT}\left(\mathrm{Kg} / \mathrm{m}^{2}\right)$ & $\mathrm{p}$ \\
\cline { 3 - 3 } & & $\mathrm{Mean} \pm \mathrm{SD}$ & \\
\hline OT & 15 & $24,59 \pm 4,50$ & 0 \\
KT & 15 & $23,49 \pm 2,60$ & 0,256 \\
\hline
\end{tabular}

OT: operative action,

KT: conservative action,

BMI: Body Mass Index

Based on table 3, the mean BMI of the OT group was higher than the mean of the BMI of the KT group $\left(24.59 \pm 4.50 \mathrm{Kg} / \mathrm{m}^{2}>23.49 \pm 2.60 \mathrm{Kg} / \mathrm{m}^{2}\right)$, but the difference was not significant ( $p>0.05)$.

\section{DISCUSSION}

Factors that increase the risk of ACL injuries include footwear, surface type, sex, ACL size, femoral notch size, menstrual cycle phase, Q angle, tibial articular surface geometry, 


\section{STRADA Jurnal Ilmiah Kesehatan}

DOI: $10.30994 /$ sjik.v9i1.263

ISSN: 2252-3847 (print); 2614-350X (online)

Vol.9 No.1. May 2020. Page.6-11

knee laxity, knee valgus, foot pronation, body mass index (BMI ) (Javad Hashemi et al., 2011), and genetic (Kenneth G. Swann. 2015). The combination of high BMI with low notch width is a predictor of ACL injury. This finding is supported by the fact that the risk is doubled in combination with these two things in women and men who have non-contact ACL injuries (Korboi N. Evans et al., 2011). High BMI increases the compression force on the knee joint, increases the risk of cartilage and meniscus injury in patients with ACL reconstruction actions (Kluczynski MA, Marzo JM, and Bisson LJ, 2017 and Bojicic KM et al., 2013 in Gulcan Harput et al., 2018 ). High BMI or in the category of obesity are more at risk of ACL injury, as a risk factor for degenerative joint disease (Volkan Kizilgoz et al., 2019).

Based on the results of the analysis, the average OT group patients included in the category of normal BMI but the maximum value of BMI showed a score of $39.34 \mathrm{~kg} / \mathrm{m}^{2}$ classified as obese and a minimum value showed a score of $17.39 \mathrm{Kg} / \mathrm{m}^{2}$ classified as thin. Meanwhile the KT group patients were also classified as normal IMT, but the maximum value showed a score of $29.68 \mathrm{~kg} / \mathrm{m}^{2}$ classified as obese. The minimum value of KT group patients is still classified as normal. This can be made possible because conservative patients are more able to control their body weight by staying actively moving after the onset of injury, while the majority of operative patients lose knee stability during preoperatively and experience a significant decrease in ROM postoperatively will experience limited mobility.

Table 4. Classification of BMI of RI Ministry of Health 2013 (I Wayan Sugiritma et al., 2015)

\begin{tabular}{ll}
\hline \multicolumn{1}{c}{ Classification } & $\begin{array}{c}\text { Body mass index (IMT) } \\
\left(\mathrm{Kg} / \mathrm{m}^{2}\right)\end{array}$ \\
\hline Thin & IMT $<18,5$ \\
Normal & IMT $\geq 18,5-<24,9$ \\
Over Weight & IMT $\geq 25,00-<27$ \\
Obesity & IMT $\geq 27,0$
\end{tabular}

BMI: Body Mass Index,

Kg: Kilogram,

$\mathrm{m}^{2}$ : height $(\mathrm{m}) \mathrm{x}$ height $(\mathrm{m})$

According to research by Ryan Bakker et al., (2015), weight is one of the risk factors for ACL injury. Having a BMI above normal is a risk factor for ACL injury in women (Helen C. Smith et al. 2012). Previous research has shown that maintaining IMT will help maintain functional long-term ACL reconstruction results (Bowers A. et al. 2005 in Rurin Ardiyani et al., 2016). In the study of Rurin Ardiyani et al (2016) the highest incidence of ACL injuries occurred in athletes with high BMI $\left(>24.9 \mathrm{~kg} / \mathrm{m}^{2}\right)$ although not statistically significant. Therefore, operative and conservative patients who are classified as overweight and obese have a greater risk of re-ACL injury than those with normal BMI. Optimal recovery and reduced risk of re-ACL injury can be supported by lowering the value of BMI until it is classified as normal.

The research results of Gulcan Harput et al., (2018), a high BMI has a negative impact on the recovery of quadriceps and hamstring strength, hop performance, and dynamic 


\section{STRADA Jurnal Ilmiah Kesehatan}

DOI: $10.30994 /$ sjik.v9i1.263

ISSN: 2252-3847 (print); 2614-350X (online)

Vol.9 No.1. May 2020. Page.6-11

balance. BMI is a risk factor for ACL injury so it is closely related to increasing success in the rehabilitation phase post ACL reconstruction. BMI must be given more attention or control because it has a negative impact on patients post ACLR.

\section{CONCLUSION}

Based on the discussions above, a high BMI value is one of the risk factors for ACL injury. Patients with ACL injuries postoperatively and conservatively have a high risk of BMI which means it could increase the risk of re-ACL injury especially in women. Physical activity and a healthy lifestyle could be applied to keep BMI normal so that it supports recovery after ACL injury.

\section{REFERENCES}

Bakker, Ryan et al. 2016. Effect of Sagital Plane Mechanics on ACL Strain During Jumping. Jurnal of Orthopaedic Research 34.

Bogardus, L. Rima et al. 2017. Applying the Socio-Ecological Model to barriers to implementation of ACL injury prevention programs: A systematic review. Journal of Sport and Health Science 10: 1-0.

Evans, N. Korboi et al. 2011. Predisposing Risk Factors for Non-contact ACL Injuries In Military Subjects. Knee Surg Sports Traumatol Arthrosc. DOI 10.1007/s00167011-1755-y.

Harput, Gulcan et al., 2018. Higher Body Mass Index Adversely Affects Knee Function After Anterior Cruciate Ligament Reconstruction in Individuals Who are Recreationally Active. Clinical Journal of Sport Medicine 00(00): 1-7.

Hashemi, Javad et al. 2011. Age, Sex Body Anthropometry, and ACL Size Predict the Structural Properties of the Human Anterior Cruciate Ligament. Journal of Orthopaedic Research. DOI 10.1002/jor.21245.

Holmquist B. \& McFarland C., 2014. Conservative Treatment of Anterior Cruciate Ligament Deficiency. Thinking Matters. Diakses pada tanggal 29 September 2018, jam 18.45 WIB. http://digitalcommons.usm.maine.edu/thinking_matters/11

Junaidi. 2013. Cedera olahraga pada atlet pelatda PON XVIII DKI Jakarta. Jurnal Fisioterapi 13 No.1:12-16.

Kizilgoz, Volkan et al. 2019. The Combined Effect of Body Mass Index and Tibial Slope Angles on Anterior Cruciate Ligament Injury Risk in Male Kness: A CaseControl Study. Clinical Medicine Insights: Arthritis and Musculoskeletal Disorders 12: 1-8.

Lin, Cheng-Feng et al. 2012. Biomechanical risk factors of non-contact ACL injuries: a stochastic biomechanical modeling study. Journal of Sport and Health Science $1: 36-42$.

Mather, C. Richard et al. 2013. Societal and Economic Impact of Anterior Cruciate Ligament Tears. The Journal of Bone and Joint Surgery 95-A (19): 1751-1759.

Muhamad I. Zein. 2013. Cedera anterior cruciate ligament (ACL) pada atlet berusia muda. Medikora 11(2):111-121.

Pfeifer, E. Craig et al. 2018. Risk Factor Associated with Non-contact Anterior Cruciate Ligament Injury: A Systematic Review. The International Journal of Sports Physical Therapy 13(4): 575-587.

RSUD Dr. Soetomo, Surabaya, 2012. Sport clinic RSUD Dr. Soetomo meningkatkan performance atlit pasca cedera lutut, RSUD Dr. Soetomo, Surabaya. 


\section{STRADA Jurnal Ilmiah Kesehatan}

DOI: $10.30994 /$ sjik.v9i1.263

ISSN: 2252-3847 (print); 2614-350X (online)

Vol.9 No.1. May 2020. Page.6-11

Rurin Ardiyani dkk. 2016. Hubungan Indeks Massa Tubuh dengan Cedera Ligamen Krusiat Anterior pada Atlet Cabang Olahraga Kontak. Jurnal Kesehatan Andalas $5(3)$.

Singh, Neraaj. 2018. International Epidemiology Anterior Cruciate Ligament Injuries. Orthopedic Research Online Journal 1(5).

Smith, C. Helen et al. 2012. Risk Factors for Anterior Cruciate Ligament Injury: A Review of the Literature-Part 1: Neuromuscular and Anatomic Risk. Sports Health 4(1).

Stephan, R. Stephen et al., 2015. Current Trends in ACL Reconstruction and Rehabilitation. SMGroup. USA.

Swann, G. Kenneth. 2015. ACL Injury: What are the Risk Factors?. University Orthopaedic Associates National Journal. 